\title{
Bisphosphonates Inhibit the Adhesion of Breast Cancer Cells to Bone Matrices In Vitro
}

\author{
Gabri van der Pluijm, Hans Vloedgraven, Ermond van Beek, Lianne van der Wee-Pals, Clemens Löwik, \\ and Socrates Papapoulos \\ Department of Endocrinology and Metabolic Diseases, University Hospital, 2333 AA Leiden, The Netherlands
}

\begin{abstract}
Bisphosphonates are used with increasing frequency in the management of skeletal complications in patients with breast cancer. In this paper, we have investigated whether bisphosphonates, besides their known beneficial effects on tumor-associated osteoclastic resorption, are capable of inhibiting breast cancer cell adhesion to bone matrix. For that we used two in vitro models for bone matrix (cortical bone slices and cryostat sections of trabecular bone from neonatal mouse tails).

Four bone matrix-bound nitrogen-containing bisphosphonates (pamidronate, olpadronate, alendronate, and ibandronate) inhibited adhesion and spreading of breast cancer cells to bone dose-dependently, whereas etidronate and clodronate had little or no effect. Strikingly, the relative order of potency of the bisphosphonates in inhibiting the adhesion of cancer cells to cortical and trabecular bone corresponded to their relative antiresorptive potencies in vivo as well as their ranking in in vitro bone resorption assays with predictive value for their clinical efficacy. It appears that nitrogen-containing bisphosphonates alter selectively the adhesive properties of the extracellular bone matrix preventing the attachment of breast cancer cells to it.

Besides the beneficial effects of bisphosphonates on tumor-induced osteoclastic resorption, the previously unrecognized effect presented in this paper makes these agents suitable for earlier pharmacologic intervention in patients with breast cancer at risk of developing bone metastases. $(J$. Clin. Invest. 1996. 98:698-705.) Key words: breast neoplasm - bisphosphonate $\cdot$ attachment $\bullet$ skeleton $\bullet$ metastasis
\end{abstract}

\section{Introduction}

Breast carcinoma metastasizes frequently to the skeleton and causes considerable morbidity and deterioration of the quality of life. The clinical consequences of skeletal metastases are bone pain, fractures, hypercalcemia, and nerve compression syndromes (1-3). The destruction of skeletal architecture at focal sites is thought to be due primarily to stimulation of os-

Address correspondence to Dr. Gabri van der Pluijm, Leiden University Hospital, Department of Endocrinology and Metabolic Diseases C4-89, 2333 AA Leiden, The Netherlands. Phone: 31-71-5263076; FAX: 31-71-5248136; E-mail: pluijm@rullf2.leidenuniv.nl.

Received for publication 16 April 1996 and accepted in revised form 4 June 1996.

J. Clin. Invest.

(C) The American Society for Clinical Investigation, Inc.

0021-9738/96/08/0698/08 \$2.00

Volume 98, Number 3, August 1996, 698-705 teoclastic bone resorption by factors secreted by the neoplastic cells (4-8). The reason for the high preference of breast cancer for the skeleton is not known. However, from the moment breast cancer cells are located in the bone microenvironment they stimulate bone resorption with a subsequent selective increase in the attraction and growth of new cancer cells to bone $(5,6,9-12)$. Therefore, any treatment aiming at palliation or perhaps even prevention of bone metastases should focus on disrupting these two steps involved in the initiation and amplification of the metastatic process.

Bisphosphonates are synthetic compounds, which are taken up preferentially by the skeleton and suppress bone resorption by inhibiting the activity of mature osteoclasts and/or the formation of new osteoclasts. For this, they are used in the treatment of patients with breast cancer and bone metastases. They have been shown to be extremely effective in the treatment of hypercalcemia and are now the treatment of choice (13). In addition, they have been shown to significantly reduce skeletal morbidity in patients with breast cancer and bone metastases and to improve certain aspects of the quality of life (14-19). Moreover, in a recently published study, Sasaki et al. (20) presented evidence that bisphosphonate treatment not only significantly decreased the progression of bone metastases in nude mice injected with breast cancer cells but, in addition, it reduced the tumor load to the skeleton.

Morphologic observations in patients with metastatic disease reveal the presence of cancer cells in the bone marrow and also on the bone surface. Tumor cells are frequently found adjacent to resorbed bone margins without evidence of resorbing osteoclasts $(8,21,22)$. In earlier studies it was already shown that breast cancer cells, apart from their action on osteoclastic resorption, may also directly destroy bone (21-23). Taken together, this evidence strongly suggests an important role for the attachment of cancer cells to bone matrix in the metastatic process. In previous studies, we and others have shown that exposure of calcified matrix of bone to bisphosphonates in vitro alters properties of the matrix required for the osteoclast (precursor) attachment to bone and subsequent differentiation into mature osteoclasts (24-29). Therefore, in this study we have investigated whether bisphosphonates may also affect the adhesive properties of breast cancer cells to extracellular bone matrix.

Our results show that bisphosphonates, in addition to their antiresorptive action, can also inhibit the adhesion of breast cancer cells to extracellular bone matrix in vitro. This previously unrecognized effect of bisphosphonates may lead to improved management of patients with breast cancer at risk of developing bone metastases.

\section{Methods}

Breast cancer cell line and cell culture conditions. The mammary carcinoma cell line MDA-MB-231 was purchased from the American 
Type Culture Collection (Rockville, MD). This estrogen receptornegative cell line was established from a single pleural effusion obtained from a 51-yr-old white woman with poorly differentiated adenocarcinoma (30). It was shown recently that MDA-MB-231 cells, when injected into the left heart ventricle of nude mice, form osteolytic metastases (references 6, 20, and our unpublished observations).

For attachment assays, tumor cells were cultured in RPMI $1640+$ $10 \%$ fetal bovine serum + penicillin/streptomycin (GIBCO-BRL Life Technologies, Breda, The Netherlands) in a humidified incubator at $37^{\circ} \mathrm{C}$ at $5 \% \mathrm{CO}_{2}$ until $\sim 90 \%$ confluency and dissociated into single cell suspensions from the tissue culture flasks using a $0.05 \%$ EDTA solution in PBS for $3 \mathrm{~min}$. No trypsin was used to avoid putative proteolytic degradation of relevant adhesion receptors by the enzyme. Cells were washed and resuspended in serum-free medium (RPMI $1640+$ ITS $^{+}$) containing $5 \mu \mathrm{g} / \mathrm{ml}$ cycloheximide. Cycloheximide was added to prevent the tumor cells from synthesizing extracellular matrix molecules (during the attachment assays) which may affect the kinetics and specificity of the adhesion assay. The viability of the cells before and after the experiments was measured by trypan blue exclusion.

Bisphosphonates. The following bisphosphonates were tested. EHDP or etidronate, $\mathrm{Cl}_{2} \mathrm{MDP}$ or clodronate, and APD or pamidronate were obtained from Henkel KGaA (Düsseldorf, Germany). Dimethyl-APD or olpadronate was obtained from Gador S.A. (Buenos Aires, Argentina), and AHBuBP or alendronate was obtained from Merck Sharp and Dohme Research Laboratories (West Point, PA). Ibandronate or BM21.0955 was a kind gift of Dr. F.H. Ebetino (Proctor \& Gamble Pharmaceuticals, Inc., Cincinnati, OH).

Structure formulas were as follows: etidronate (EHDP), 1-hydroxyethylidene-1,1-bisphosphonic acid; clodronate $\left(\mathrm{Cl}_{2} \mathrm{MDP}\right)$, dichloromethylene bisphosphonate; pamidronate (APD), 3-amino-1-hydroxypropylidene-1,1-bisphosphonate; olpadronate (dimethyl-APD), dimethylamino-1-hydroxypropylidene-1,1-bisphosphonate; alendronate (AH-

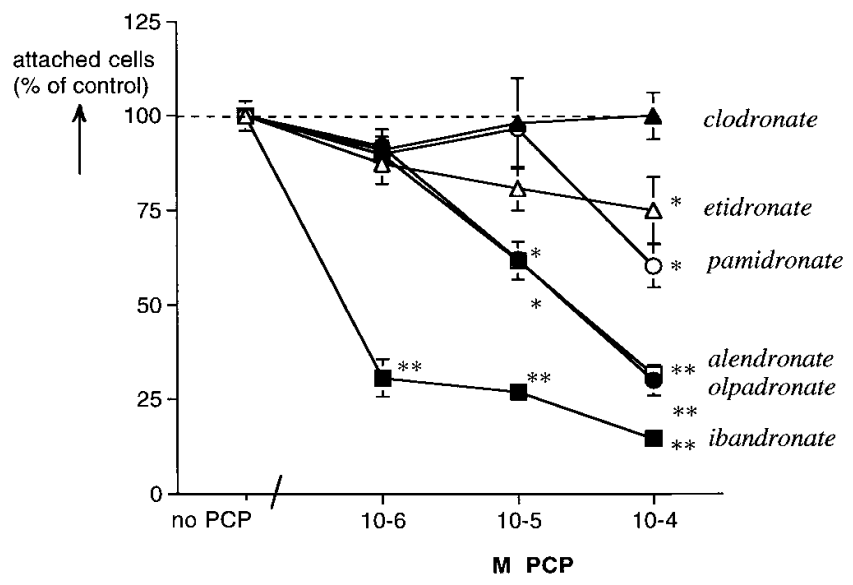

Figure 1. Dose-response relationships of various bisphosphonates on adhesion of mammary carcinoma cells (MDA-MB-231) to bovine cortical bone slices. After $18 \mathrm{~h}$ of pretreatment of the bone slices with varying concentrations of bisphosphonate, breast cancer cells $(100,000$ cells $/ 500 \mu l$ serum-free medium $)$ were seeded for $3 \mathrm{~h}$ on bisphosphonate-pretreated bone slices at $37^{\circ} \mathrm{C}$. Each experimental group was performed in fourfold and experiments were repeated at least three times. The values are expressed as treatment/control (= bisphosphonate/no bisphosphonate pretreatment). The bars indicate SEM and significances were calculated using one-way ANOVA followed by a Fisher's PLSD test. Absolute control values (cells $\left./ \mathrm{mm}^{2}\right)$ were: $333 \pm 28$ (etidronate), $204 \pm 14$ (clodronate), $222 \pm 6$ (pamidronate), $195 \pm 8$ (olpadronate), $222 \pm 6$ (alendronate), $333 \pm 28$ (ibandronate). Open triangles, etidronate; closed triangles, clodronate; open circles, pamidronate; closed circles, olpadronate; open squares, alendronate; closed squares, ibandronate.
BuBP), 4-amino-1-hydroxybutylidene-1,1-bisphosphonate; ibandronate (BM21.0955), 1-hydroxy-3-(methylpentylamino)propylidene-1,1-bisphosphonic acid.

Adhesion of breast cancer cells to cortical bone slices. Bovine cortical bone slices, a kind gift of Dr. Tiina Laitala (University of Oulu, Oulu, Finland), were preincubated for $18 \mathrm{~h}$ in $2 \mathrm{ml}$ serum-free medium with varying concentrations of bisphosphonates $\left(10^{-6}\right.$ to $\left.10^{-4} \mathrm{M}\right)$.

Subsequently, the wells were washed twice with $1 \mathrm{ml}$ of serumfree RPMI 1640 culture medium and preincubated for $30 \mathrm{~min}$ in serum-free medium RPMI 1640 supplemented with glutamine, and $0.5 \%$ insulin-transferrin-selenite-bovine serum albumin (ITS ${ }^{+}$; GIBCO-BRL Life Technologies) at $37^{\circ} \mathrm{C}$ in a humidified incubator $\left(5 \% \mathrm{CO}_{2}\right)$. Subsequently, the medium was removed and tumor cells were seeded on top of these slices at a density of 100,000 cells/500 $\mu \mathrm{l}$ serum-free medium $\left(\right.$ RPMI $1640+\mathrm{ITS}^{+}$) and incubated for $3 \mathrm{~h}$. After incubation the bone slices were removed from the wells and washed three times in PBS, fixed for 30 min with $500 \mu \mathrm{l} 3 \%$ paraformaldehyde in PBS containing 2\% sucrose. Bone slices were stained for 8 min with $1 \%$ toluidine blue in $1 \%$ sodium borate and, after fixation, washed three times with PBS and mounted on glass coverslips with Histomount (National Diagnostics-Brunschwig Chemie, Amsterdam, the Netherlands). Stained bone slices were kept dark before histologic examination. Cells located within two nonoverlapping microscopic fields were counted $(=2.54$ $\mathrm{mm}^{2}$ ) for each bone slice. Each experimental group was performed in fourfold and experiments were repeated at least three times.

After fixation and staining the number of nonspread cells was determined by counting the same microscopic fields as described above. All round-shaped cells, that lack cytoplasmic extrusions, were counted. Subsequently the percentage of nonspread cells was calculated as follows: percent nonspread cells $=$ ([number of nonspread cells]/[total number of cells]) $\times 100 \%$.

Adhesion of breast cancer cells to cryostat sections of developing trabecular bone. 2-d-old neonatal mice (Swiss Albino) were killed

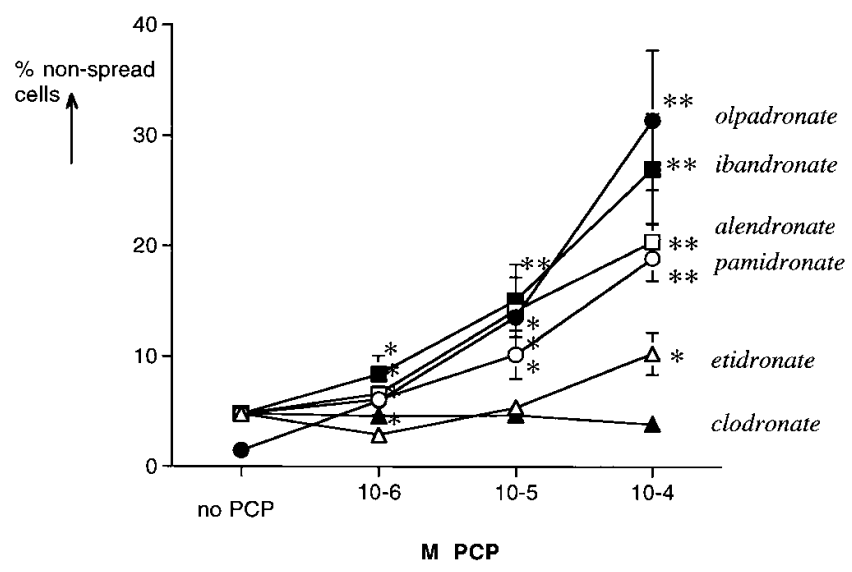

Figure 2. Dose-response relationships of various bisphosphonates on the percentage of nonspread, adherent mammary carcinoma cells (MDA-MB-231) to bovine cortical bone slices. After $18 \mathrm{~h}$ of pretreatment of the bone slices with varying concentrations of bisphosphonate, breast cancer cells $(100,000$ cells/500 $\mu$ l serum-free medium) were seeded for $3 \mathrm{~h}$ on bisphosphonate-pretreated bone slices at $37^{\circ} \mathrm{C}$. The values are expressed as treatment/control (= bisphosphonate/no bisphosphonate pretreatment). Each experimental group was performed in fourfold and experiments were repeated at least three times. The bars indicate SEM and significances were calculated using one-way ANOVA followed by a Fisher's PLSD test. Absolute control values (cells $/ \mathrm{mm}^{2}$ ) were: $15 \pm 6$ (etidronate), $6 \pm 2$ (clodronate), $11 \pm 2$ (pamidronate), $3 \pm 1$ (olpadronate), $11 \pm 2$ (alendronate), $15 \pm 6$ (ibandronate). Open triangles, etidronate; closed triangles, clodronate; open circles, pamidronate; closed circles, olpadronate; open squares, alendronate; closed squares, ibandronate. 

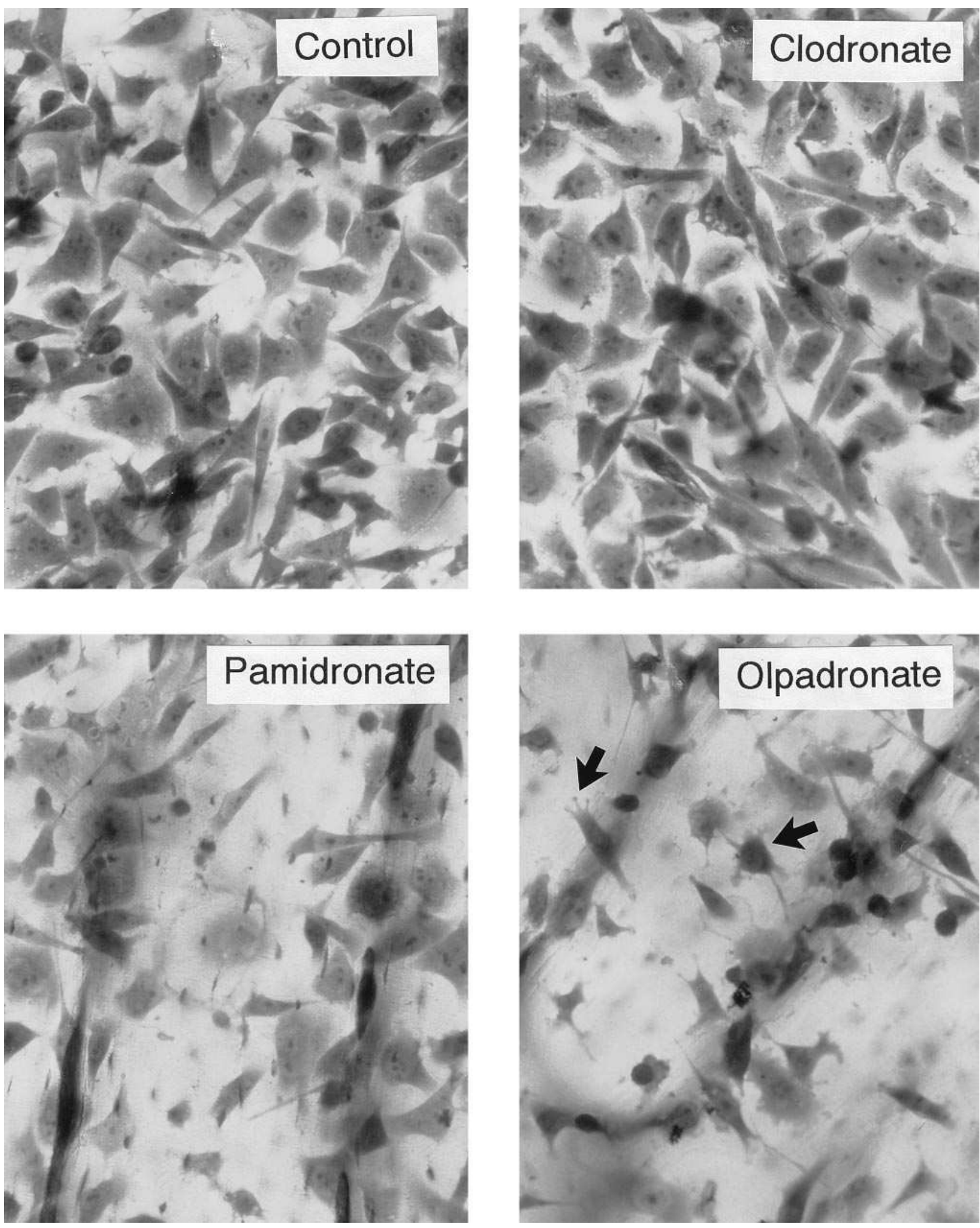

Figure 3. Representative micrographs of MDA-MB-231 mammary carcinoma cells after $3 \mathrm{~h}$ of incubation on bovine cortical bone slices under control conditions and after pretreatment with $10^{-4} \mathrm{M}$ of bisphosphonate for $18 \mathrm{~h}$. Nonspread cells can be recognized as round-shaped or stellate-shaped cells (see arrows). Original magnification of 200. 
and their tails were dissected, stretched in Tissue Tek (Miles Scientific, Naperville, IL), frozen in liquid $\mathrm{N}_{2}$ for at least $10 \mathrm{~min}$ and stored at $-80^{\circ} \mathrm{C}$ as described before (31). 5- $\mu \mathrm{m}$ sections were cut at $-20^{\circ} \mathrm{C}$ using a cryostat (Microm HM $500 \mathrm{M}$ ) and subsequently transferred to 3-aminopropyltriethoxy-silane (Sigma Chemical Co., St. Louis, MO) coated glass coverslips and stored at $-80^{\circ} \mathrm{C}$ until use.

Before adhesion experiments the cryostat sections were air dried at room temperature for $30 \mathrm{~min}$. Around each tissue section a (hydrophobic) line was drawn with a DAKO pen (code No. S 2002; DAKO $\mathrm{A} / \mathrm{S}$, Copenhagen, Denmark) to avoid spreading of the cell suspension over the entire glass coverslip area. Subsequently, Tissue Tek was removed by incubating the sections for $5 \mathrm{~min}$ in a large volume of PBS. The sections were incubated at $4^{\circ} \mathrm{C}$ with $100 \mu \mathrm{l}$ of PBS $+2 \%$ $\mathrm{wt} / \mathrm{vol} \mathrm{BSA}-$ fraction $\mathrm{V}$ for $2 \mathrm{~h}$ to avoid nonspecific binding. The effects of bisphosphonates on adhesion of mammary carcinoma cells were determined after pretreatment of cryostat sections with $100 \mu \mathrm{l}$ of bisphosphonates for $2 \mathrm{~h}$ at varying concentrations $\left(10^{-6}\right.$ to $\left.10^{-4} \mathrm{M}\right)$. Subsequently, the bisphosphonate solution was removed and the sections were washed twice with PBS before the tumor cells were seeded on top of the tail sections according to the method described below. Values are expressed as the percentage of control (no bisphosphonate pretreatment) in which the treated group represents the bisphosphonate-pretreated sections.

Tumor cells were resuspended in serum-free medium (RPMI $\left.1640+\mathrm{ITS}^{+}\right)$, counted and seeded at a density of 100,000 cells in 100 $\mu l$ medium onto longitudinal mouse tail sections, and incubated for $1 \mathrm{~h}$ at $37^{\circ} \mathrm{C}$ in a humidified incubator $\left(5 \% \mathrm{CO}_{2}\right)$. After incubation the sections were washed three times with PBS (to remove nonadherent cells) and attached cells were fixed in $4 \%$ paraformaldehyde for 30 min. Subsequently, the sections were washed with PBS and stained with hematoxylin for $2 \mathrm{~min}$. The hematoxylin was removed and the stained sections were washed in running tap water for several minutes. The sections were mounted in Histomount (National Diagnostics-Brunschwig Chemie, Amsterdam, The Netherlands) and covered with coverslips.

Two separate areas were counted within each tail sections: (calcified) vertebrae and their noncalcified surrounding tissue consisting of muscle and skin. Cell numbers were determined by counting one mi- croscopic field for each central section of vertebrae 16 and 17 (and their surrounding tissue) at an original magnification of 200. The central sections of the tail were made from the same animal and used for control and experimental groups. The experiments were performed in sixfold and repeated twice.

Statistics. Significance between the experimental groups within each experiment was calculated using a factorial one-way ANOVA followed by a Fisher's PLSD test.

\section{Results}

Six bisphosphonates (etidronate, clodronate, pamidronate, olpadronate, alendronate, and ibandronate) were tested for their ability to interfere with the adhesion of human mammary carcinoma cells (MDA-MB-231) to cortical and trabecular bone matrices.

Bovine cortical bone slices (calcified bone matrix) were pretreated for $18 \mathrm{~h}$ with varying concentrations of bisphosphonates $\left(10^{-6}\right.$ to $\left.10^{-4} \mathrm{M}\right)$. Subsequently, the bone slices were washed three times in PBS to remove nonbound bisphosphonate before breast cancer cells were seeded on top of the bisphosphonate-pretreated bone matrix. Under control conditions (no bisphosphonate pretreatment), MDA-MB-231 cells adhere to cortical bone within $3 \mathrm{~h}$ and subsequently spread. Nearly all adherent cells (95\%) spread on the bone substrate within $2 \mathrm{~h}$. Pretreatment of bone slices with clodronate and etidronate between $10^{-6}$ and $10^{-4} \mathrm{M}$ had little or no effect on the adhesion of breast cancer to these slices (Fig. 1). In contrast, pretreatment of the bone slices with the four nitrogencontaining bisphosphonates (pamidronate, olpadronate, alendronate, and ibandronate) inhibited the adhesion of breast cancer cells dose-dependently (Fig. 1). There were differences in potencies among these four nitrogen-containing bisphosphonates with ibandronate being the most potent of the four. The order of potency of the six tested compounds corresponds

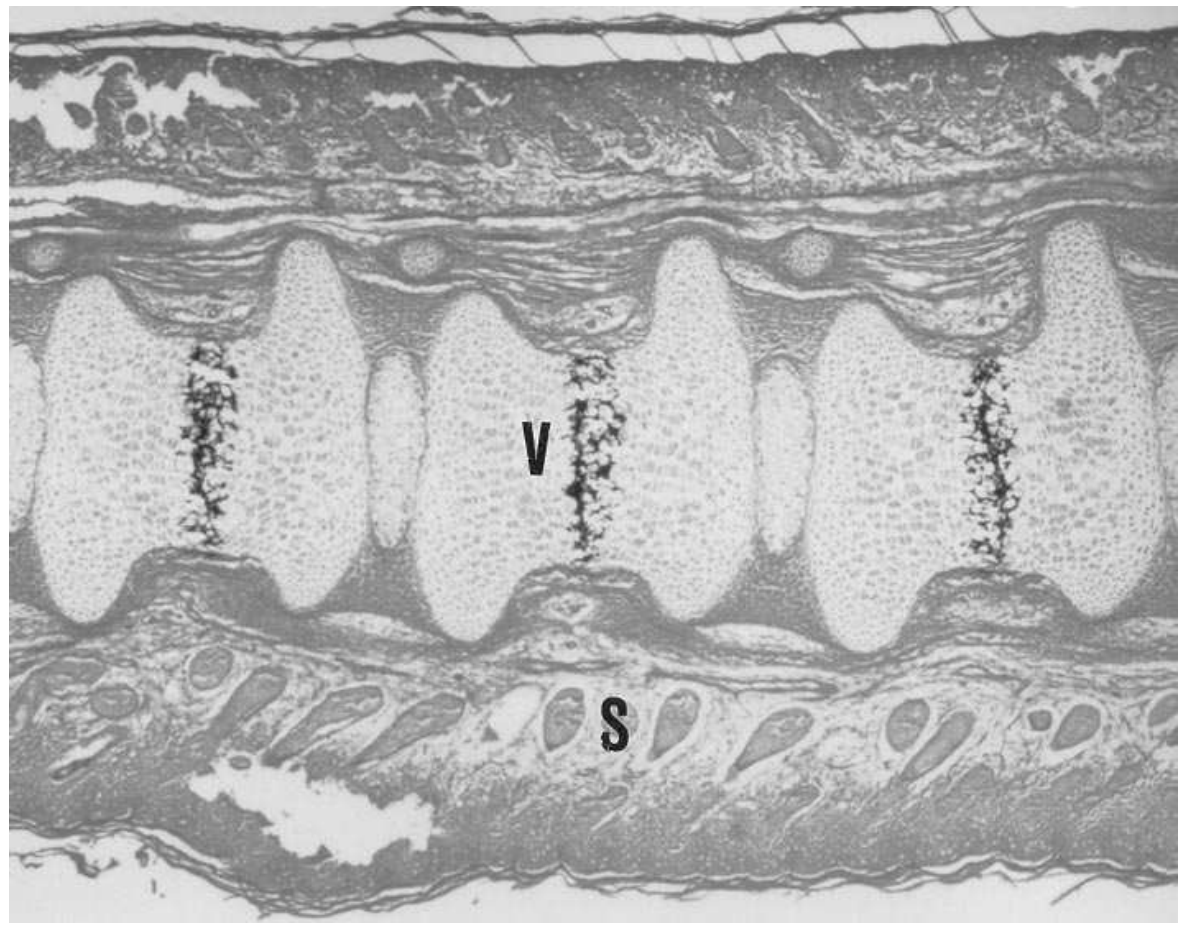

Figure 4. Micrographs of a longitudinal section (vertebrae 15-17) of the midregion of a 2-d-old neonatal mouse tail. The calcified areas of the vertebrae present in the tail section were stained black using von Kossa staining (48). Original magnification of 100 . $V$, vertebrae; $S$, surrounding tissue. 
Figure 5. (A) Dose-response relationships of various bisphosphonates on adhesion of mammary carcinoma cells (MDA-MB-231) to caudal vertebrae 16 and 17 consisting of calcified cartilage matrix. After $2 \mathrm{~h}$ of pretreatment of the cryostat tail sections with varying concentrations of bisphosphonate, breast cancer cells $(100,000$ cells/ $100 \mu \mathrm{l}$ serum-free medium) were seeded for $3 \mathrm{~h}$ on to bisphosphonate-pretreated tail sections at $37^{\circ} \mathrm{C}$. Each experimental group was performed in sixfold and experiments were repeated twice. The values are expressed as treatment/control (= bisphosphonate/no bisphosphonate pretreatment). A representative experiment is shown. The bars indicate SEM and significances were calculated using oneway ANOVA followed by a Fisher's PLSD test. Absolute control value $=98 \pm 9\left(\right.$ cells $\left./ \mathrm{mm}^{2}\right)$. Open triangles, etidronate; closed triangles, clodronate; open circles, pamidronate; closed circles, olpadronate; open squares, alendronate; closed squares, ibandronate. (B) Effects of bisphosphonate pretreatment at $10^{-4} \mathrm{M}$ on adhesion of mammary carcinoma cells to muscle and skin tissues surrounding vertebrae 16 and 17. Each experimental group was performed in sixfold and experiments were repeated twice. The values are expressed as treatment/control ( $=$ bisphosphonate/no bisphosphonate pretreatment). A representative experiment is shown. The bars indicate SEM and significances were calculated using one-way ANOVA followed by a Fisher's PLSD test. Absolute control value $=99 \pm 12\left(\right.$ cells $\left./ \mathrm{mm}^{2}\right)$.

to their ranking in bone resorption assays representative of their relative potencies in vivo (24-28, 32-34). In addition to their effect on adhesion of the breast cancer cells to cortical bone slices, all four nitrogen-containing bisphosphonates tested decreased significantly and dose-dependently the spreading of breast cancer cells while etidronate and clodronate had little or no effect. This is illustrated in Fig. 2 where the fraction of nonspread adherent cells was calculated as described in Methods.

In Fig. 3 histological examples of control and bisphosphonate-treated cortical bone slices are shown. There were no differences in adhesion and spreading of cancer cells between control and clodronate-treated bone slices. At equimolar concentrations, pamidronate and olpadronate pretreatment not only decreased the adhesion and spreading of the malignant cell but also altered their morphology. Cells were more rounded, less spread, and frequently displayed cytoplasmic extrusions (Fig. 3), whereas their viability was not affected as determined by trypan blue exclusion ( $>95 \%$ viable cells at all bisphosphonate concentrations tested).

The effects of bisphosphonates on adhesion of breast cancer cells to bone matrix were further tested using another in vitro attachment assay of trabecular bone. In longitudinal sections $(5 \mu \mathrm{M})$ through a 2-d-old neonatal mouse tail (Fig. 4, caudal vertebrae 16-18), the mid-region and proximal end of the cryostat tail section consist of calcified trabeculae $(31,35)$.

Therefore, using a single cryostat section it is possible to test the ability of breast cancer cells to adhere to the vertebrae as well as to adjacent nonskeletal tissues (muscle, skin). Mammary carcinoma cells (MDA-MB-231) settled and spread on longitudinal cryostat sections of mouse tail vertebrae. Pretreatment of these tail sections with bisphosphonates at varying concentrations differentially affected breast cancer cell adhesion (Fig. 5). Adhesion of mammary carcinoma cells to vertebrae was inhibited selectively and dose-dependently after pretreatment with the nitrogen-containing bisphosphonates (Fig. $5 \mathrm{~A}$ ). In contrast, no inhibition was found with etidronate and clodronate at all concentrations tested. These data are in total agreement with those obtained in cortical bone slices. Furthermore, the order of potency of the tested bisphosphonates again corresponded to their ranking in bone resorption assays. In contrast, bisphosphonate pretreatment had no effect on the adhesion of tumor cells to tissues directly adjacent to these vertebrae (surrounding tissue, Fig. 5 B). Fig. 6 depicts the morphological appearance of MDA-MB-231 mammary carcinoma cells on the calcified matrix of vertebrae and their (nonmineralized) surrounding tissues after pretreatment with the nitrogen-containing bisphosphonate ibandronate ( $c$ and $d$ ) and their respective controls $(a$ and $b)$. Thus, it appears that the effects of bisphosphonates on the adhesion of tumor cells are specific for the mineralized bone matrix.

\section{Discussion}

Bisphosphonates are powerful pharmacologic tools for the management of skeletal complications in patients with breast cancer $(1-4,11,13-19,36)$. In this paper, we have investigated whether bisphosphonates, besides their beneficial effects on tumor-associated osteoclastic resorption, are capable of inhibiting breast cancer cell adhesion to bone matrix. For this we used an in vitro model (cortical bone slices) to study the effects of bisphosphonates with variable structures and antiresorptive potencies on cellular adhesion. This well established in vitro model is mainly used to study the resorptive capacity of adherent osteoclasts $(29,37,38)$. In addition, we used cryostat sections of neonatal mouse tails, a recently described, convenient, 

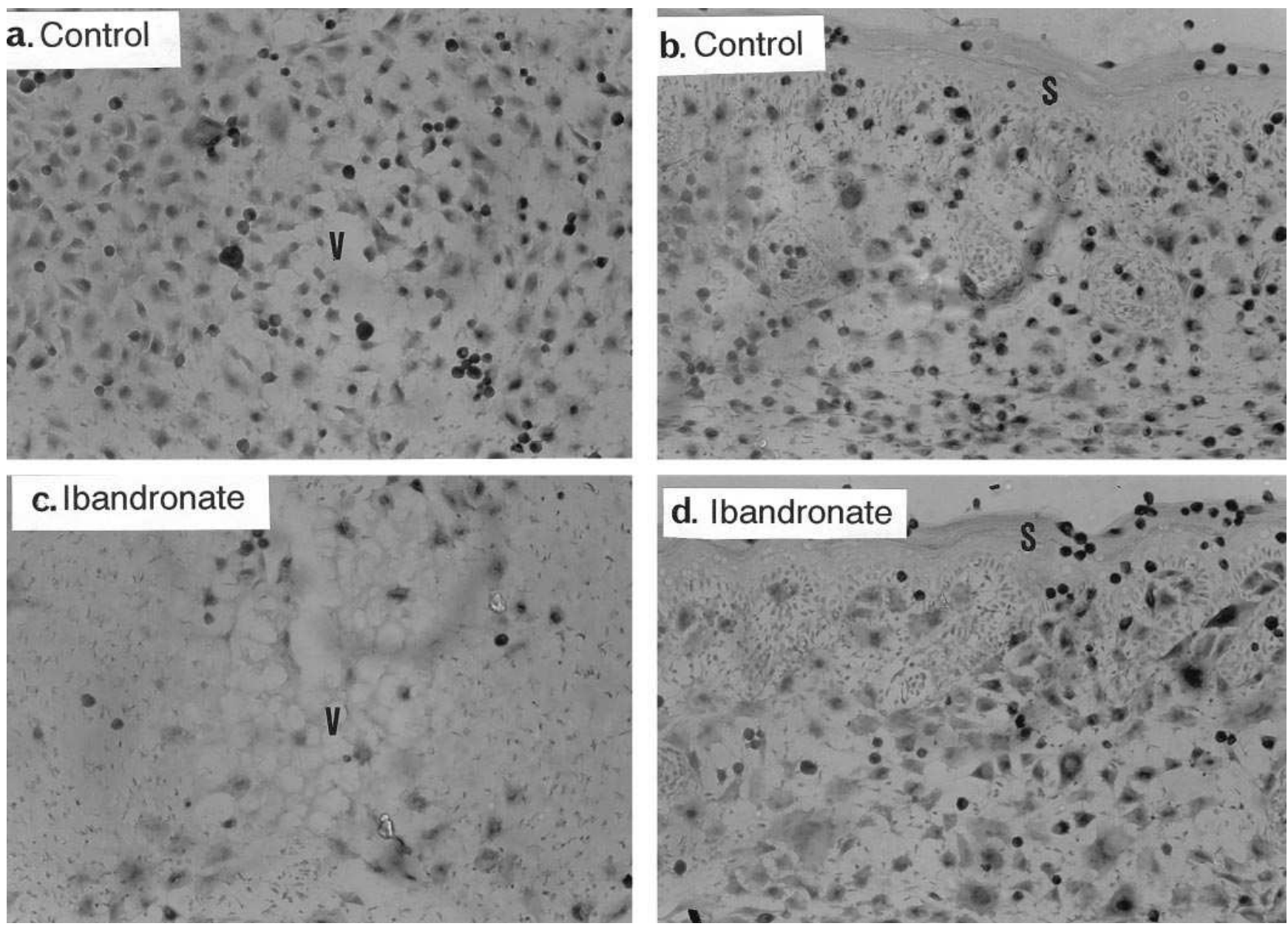

Figure 6. Appearance of breast cancer cells on the mineralized bone matrix of caudal vertebra 17 and its adjacent tissue (muscle and skin). Breast cancer cells strongly adhere to the mineralized bone matrix of vertebrae $(a)$ and their adjacent tissue $(b)$. Pretreatment with nitrogen-containing bisphosphonates, as depicted here for ibandronate, selectively inhibited the attachment to the calcified matrices of vertebrae (c), whereas no inhibition of cellular attachment was found after pretreatment of nonmineralized adjacent tissue $(d)$. Original magnification of 200. $V$, vertebra; $S$, skin.

and reliable method to study adhesion characteristics of breast cancer cells to trabecular bone (caudal vertebrae) (31). Within each cryostat section evaluation of the cellular adhesion to adjacent tissue may further improve the interpretation of the results and provide a clue for putative tissue specificity.

We show here that breast cancer cells adhere rapidly to extracellular bone matrix and we present direct evidence that adhesion to extracellular bone matrix can be modulated after pretreatment of cortical or trabecular bone with bisphosphonates. All four matrix-bound potent nitrogen-containing bisphosphonates (pamidronate, olpadronate, alendronate, and ibandronate) inhibited the adhesion of MDA-MB-231 mammary carcinoma cells to cortical bone slices and mouse tail vertebrae dose-dependently. Pretreatment of both cortical and trabecular bone matrices with clodronate and etidronate, however, had no significant effect on cellular attachment at the concentration range tested. Moreover, the antiadhesive effect of nitrogen-containing bisphosphonates was bone specific since pretreatment of nonmineralized tissues with bisphosphonates did not affect adhesion of the breast cancer cells. In addition, we showed that the number of nonspread adherent cells increased proportionally with increasing concentrations of ni- trogen-containing bisphosphonates. Thus, matrix-bound bisphosphonates appear to act on breast cancer cells by inhibiting the initial attachment as well as their subsequent spreading on extracellular bone matrix. The mechanism underlying this antiadhesive property of the nitrogen-containing bisphosphonates cannot be deduced from our studies. Strikingly, however, the ranking of potencies of the tested bisphosphonates correlates closely with their relative potencies in inhibiting osteoclastic resorption in vivo and in in vitro bone resorption models that are predictive for their in vivo efficacy $(24-28,32-34$, $36,39,40)$.

It has been shown earlier that bone matrix-bound bisphosphonates may suppress osteoclastic resorption not only through inhibition of the activity of osteoclasts, but also by inhibiting the adhesion of osteoclast precursors and their subsequent differentiation into mature resorbing osteoclasts $(24-28,32)$. Recent studies suggested that they may also inhibit the attachment of mature osteoclasts to cortical bone slices (29). It may be that comparable mechanisms underlie the observed effects of bisphosphonates on recognition of extracellular bone matrix by breast cancer cells. For example, they may interfere with matrix-bound factors that are responsible for adhesion (i.e., at- 
tachment proteins) and/or specific matrix signals needed for recognition of bone by normal cells (i.e., osteoclast precursors) or malignant cells of osteotropic tumors (i.e., breast cancer cells). The vitronectin receptor, which is highly expressed in osteoclasts, is important for the adhesion of osteoclasts (precursors) to bone matrix (41), osteoclast migration, and osteoclastic resorption (42-44). Breast cancer cells express integrins which recognize specifically certain bone matrix proteins $(45$, 46) and we recently demonstrated specific interactions between breast cancer cells with the bone-specific protein BSP (31). In addition, it has been shown recently that the expression of the $\beta_{3}$ integrin, a structural component of the vitronectin receptor, is enhanced in skeletal metastatic sites (47). Thus, we may be dealing with cell-matrix interactions of a more general nature which can be modulated by bisphosphonates.

Accumulating clinical evidence suggests further that the overall efficacy of bisphosphonates on skeletal metastases is not solely due to their action on bone resorption. Although all studies reported so far have demonstrated significant reduction in skeletal morbidity in patients with breast cancer by bisphosphonates, their effect is incomplete and dose dependent (18). Our present study, showing that bisphosphonate doses higher than those required for the suppression of bone resorption are needed for the inhibition of the attachment of breast cancer cells to bone matrix, is in line with the clinical observations. Our findings further suggest that certain bisphosphonates may be suitable for earlier intervention in breast cancer patients at risk of developing bone metastases by arresting the adhesion of cancer cells to bone. Although this is speculative at present, evaluation of the previously unrecognized action of bisphosphonates, described here, certainly warrants further in vivo investigation.

\section{Acknowledgments}

This work was supported by a grant from the Dutch Cancer Society (IKW 93-580).

\section{References}

1. Elte, J.W.F., O.L.M. Bijvoet, F.J. Cleton, A.T. van Oosterom, and H.P. Sleeboom. 1986. Osteolytic metastases in breast carcinoma. Pathogenesis, morbidity and bisphosphonate treatment. Eur. J. Cancer Clin. Oncol. 22:493-500.

2. Paterson, A.H.G. 1987. Bone metastases in breast cancer, prostate cancer and myeloma. Bone. 8(Suppl. 1):S17-S22.

3. Coleman, R.E., and R.D. Rubens. 1987. The clinical course of bone metastases from breast cancer. Br. J. Cancer. 55:61-66.

4. Kanis, J.A., R.E. Gray, G. Urwin, S. Murray, and N. Hamdy. 1987. Physiology of bone and metabolic approaches to the treatment of skeletal metastases. Dev. Oncol. 51:303-322.

5. Mundy, G.R. 1991. Mechanisms of osteolytic bone destruction. Bone. 12(Suppl. 1):S1-S6.

6. Yoneda, T., A. Sasaki, and G.R. Mundy. 1994. Osteolytic bone disease in breast cancer. Breast Cancer Res. Treat. 32:73-84.

7. Galasko, C.S.B. 1982. Mechanisms of lytic and blastic metastatic disease of bone. Clin. Orthop. 169:20-27.

8. Garrett, I.R. 1993. Bone destruction in cancer. Semin. Oncol. 20:4-9.

9. Kostenuik, P.J., G. Singh, K.L. Suyama, and F.W. Orr. 1992. Stimulation of bone resorption results in a selective increase in growth rate of spontaneously metastatic Walker 256 cancer cells in bone. Clin. Exp. Metastasis. 10:411418.

10. Krempien, B., and C. Manegold. 1993. Prophylactic treatment of skeletal metastases, tumor-induced osteolysis, and hypercalcemia in rats with the bisphosphonate $\mathrm{Cl}_{2} \mathrm{MBP}$. Cancer (Philadelphia). 72:91-98.

11. Kanis, J.A., E.V. Mc Closkey, T. Taube, and N. O'Rourke. 1991. Rationale for the use of bisphosphonates in bone metastases. Bone. 12(Suppl. 1):S13S18.

12. Orr, F.W., P. Kostenuik, O.H. Sanchez-Sweatman, and G. Singh. 1993.
Mechanisms involved in the metastasis of cancer to bone. Breast Cancer Res. Treat. 25:151-163.

13. Fleisch, H. 1991. Bisphosphonates: pharmacology and use in the treatment of tumor-induced hypercalcemic and metastatic bone disease. Drugs. 42: 919-944.

14. Elooma, I., C. Blomqvist, P. Gröhn, L. Porkka, A.-L. Kairento, K. Selander, C. Lamberg-Allardt, and T. Holmström. 1983. Long-term controlled trial with diphosphonate in patients with osteolytic bone metastases. Lancet. i: 146-149.

15. van Holten-Verzantvoort, A.T.M., O.L.M. Bijvoet, F.J. Cleton, J. Hermans, H.M. Kroon, H.I.J. Harinck, P. Vermeer, J.W.F. Elte, J.P. Neijt, L.V.A.M Beex, and G. Blijham. 1987. Reduced morbidity from skeletal metastases in breast cancer patients during long-term bisphosphonate (APD) treatment. Lancet. ii:983-985.

16. van Holten-Verzantvoort, A.T.M., A.H. Zwinderman, N.K. Aaronson, J. Hermans, B. van Emmerik, F.S.A.M. van Dam, B. van den Bos, O.L.M. Bijvoet, and F.J. Cleton. 1991. The effect of supportive pamidronate treatment on aspects of quality of life of patients with advanced breast cancer. Eur. J. Cancer. 27:544-549.

17. Paterson, A.H.G., T.J. Powles, J.A. Kanis, E. McCloskey, J. Hanson, and S. Ashley. 1993. Double-blind controlled trial of oral clodronate in patients with bone metastases from breast cancer. J. Clin. Oncol. 11:59-65.

18. van Holten-Verzantvoort, A.T.M., H.M. Kroon, O.L.M. Bijvoet, F.J. Cleton, L.V.A.M. Beex, G. Blijham, J. Hermans, J.P. Neijt, S.E. Papapoulos, H.P. Sleeboom, et al. 1993. Palliative pamidronate treatment in patients with bone metastases from breast cancer. J. Clin. Oncol. 11:491-498.

19. van Holten-Verzantvoort, A.T.M. 1995. Bisphosphonate treatment of metastatic bone disease from breast cancer. In Bisphosphonate Therapy in Acute and Chronic Bone Loss. O. Bijvoet, H.A. Fleisch, R.E. Canfield, and G. Russell, editors. Elsevier Science B.V., Amsterdam. 365-377.

20. Sasaki, A., B.F. Boyce, B. Story, K.R. Wright, M. Chapman, R. Boyce, G.R. Mundy, and T. Yoneda. 1995. Bisphosphonate risedronate reduces metastatic human breast cancer burden in bone in nude mice. Cancer Res. 55:35513557.

21. Galasko, C.S.B. 1976. Mechanisms of bone destruction in the development of skeletal metastases. Nature (Lond.). 263:507-508.

22. Galasko, C.S.B., and A. Bennet. 1976. Relationship of bone destruction in skeletal metastases to osteoclast activation and prostaglandins. Nature (Lond.). 263:508-510

23. Eilon, G., and G.R. Mundy. 1978. Direct resorption of bone by human breast cancer cells in vitro. Nature (Lond.). 276:726-728.

24. Boonekamp, P.M., L.J.A. van der Wee-Pals, M. van Wijk-van Lennep, C.W. Thesingh, and O.L.M. Bijvoet. 1986. Two modes of action of bisphosphonates on osteoclastic resorption of mineralized matrix. Bone Miner. 1:27-40.

25. Boonekamp, P.M., C.W.G.M. Löwik, L.J.A. van der Wee-Pals, M.M.L. van Wijk-van Lennep, and O.L.M. Bijvoet. 1987. Enhancement of the inhibitory action of APD on the transformation of osteoclasts precursors into resorbing cells after dimethylation of the amino group. Bone Miner. 2:29-42.

26. Löwik, C.W.G.M., G. van der Pluijm, L.J.A. van der Wee-Pals, H. Bloys-van Treslong-de Groot, and O.L.M. Bijvoet. 1988. Migration and phenotypic transformation of osteoclasts precursors into mature osteoclasts: the effect of a bisphosphonate. J. Bone Miner. Res. 3:185-192.

27. van der Pluijm, G., L. Binderup, E. Bramm, L. van der Wee-Pals, H. de Groot, E. Binderup, C. Löwik, and S. Papapoulos. 1992. Disodium 1-hydroxy3-(1-pyrrolidinyl)-propylidene-1,1-bisphosphonate (EB-1053) is a potent inhibitor of bone resorption in vitro and in vivo. J. Bone Miner. Res. 7:981-986.

28. Löwik, C., and G. van der Pluijm. 1995. Mechanisms of action of bisphosphonates: studies with bone culture systems. In Bisphosphonate Therapy in Acute and Chronic Bone Loss. O. Bijvoet, H.A. Fleisch, R.E. Canfield, and G. Russell, editors. Elsevier Science B.V., Amsterdam. 155-170.

29. Colucci, S., V. Minielli, G. Zambonin, and M. Grano. 1995. Alendronate acts on bone resorption of human osteoclast-like cells through the inhibition of cell attachment to bone surfaces. Bone. 17:599 (Abstr.)

30. Cailleau, R., R. Young, M. Olivé, and W.J. Reeves. 1974. Breast tumor cell lines from pleural effusions. J. Natl. Cancer Inst. 53:661-674.

31. van der Pluijm, G., H.J.M. Vloedgraven, B. Ivanov, F.A. Robey, W.J. Grzesik, P. Gehron Robey, S.E. Papapoulos, and C.W.G.M. Löwik. 1996. Bone sialoprotein peptides are potent inhibitors of breast cancer cell adhesion to bone. Cancer Res. 56:1948-1955.

32. Papapoulos, S.E., K. Hoekman, C.W.G.M. Löwik, P. Vermeij, and O.L.M. Bijvoet. 1989. Application of an in vitro model and a clinical protocol in the assessment of the potency of a new bisphosphonate. J. Bone Miner. Res. 4: $775-781$.

33. Green, J.R., K. Müller, and K.A. Jaeggi. 1994. Preclinical pharmacology of CGP 42'446, a new, potent, heterocyclic bisphosphonate compound. J. Bone Miner. Res. 9:745-751.

34. Mühlbauer, R., F. Bauss, R. Schenk, M. Janner, E. Bosies, K. Strein, and H. Fleisch. 1991. BM21.0955, a potent new bisphosphonate to inhibit bone resorption. J. Bone Miner. Res. 6:1003-1011.

35. Marks, S.C., Jr., and D.C. Hermey. 1996. Principles in bone biology. In The Structure and Development of Bone. J. Bilezekian, L. Riasz, and G. Rodan, editors. Academic Press, New York. 
36. Geddes, A.D., S.M. D’Souza, F.H. Ebetino, and K.J. Ibbotson. 1994. Bisphosphonates: structure-activity relationships and therapeutic implications. In Bone and Mineral Research. Volume 8. J.N.M. Heersche and J.A. Kanis, editors. Elsevier Science B.V., Amsterdam. 265-306.

37. Chambers, T.J., R.A. Revell, K. Fuller, and N.A. Athanasou. 1984. Resorption of bone by isolated rabbit osteoclasts. J. Cell Sci. 66:383-399.

38. Sato, M., and W.A. Grasser. 1990. Effects of bisphosphonates on isolated rat osteoclasts as examined by reflected light microscopy. J. Bone Miner. Res. 5:31-40.

39. Schenk, R., P. Eggli, R. Felix, H. Fleisch, and S. Rosini. 1986. Quantitative morphometric evaluation of the inhibitory activity of new aminobisphosphonates on bone resorption in the rat. Calcif. Tissue Int. 38:342-349.

40. Sietsema, W.K., F.H. Ebetino, A.M. Salvago, and J.A. Bevan. 1989. Antiresorptive dose-response relationships across three generations of bisphosphonates. Drugs Exp. Clin. Res. 15:389-396.

41. van der Pluijm, G., H. Mouthaan, C. Baas, H. de Groot, S. Papapoulos, and C. Löwik. 1994. Integrins and osteoclastic resorption in three bone organ cultures: differential sensitivity to synthetic Arg-Gly-Asp peptides during osteoclasts formation. J. Bone Miner. Res. 9:1021-1028.

42. Davies, J., J. Warwick, N. Totty, R. Philip, M. Helfrich, and M. Horton. 1989. The osteoclast functional antigen, implicated in the regulation of bone re- sorption, is biochemically related to the vitronectin receptor. J. Cell Biol. 109: 1817-1826.

43. Helfrich, M.H., S.A. Nesbitt, E.L. Dorey, and M.A. Horton. 1992. Rat osteoclasts adhere to a wide range of RGD (Arg-Gly-Asp) peptide-containing proteins, including the bone sialoproteins and fibronectin, via a beta 3 integrin. J. Bone Miner. Res. 7:335-343.

44. Ross, F.P., J. Chappel, J.I. Alvarez, D. Sander, W.T. Butler, M.C. Farach-Carson, K.A. Mintz, P.G. Robey, S.L. Teitelbaum, and D.A. Cheresh 1993. Interactions between bone matrix proteins osteopontin and bone sialoprotein and the osteoclast integrin alpha v beta 3 potentiate bone resorption. $J$. Biol. Chem. 268:9901-9907.

45. van der Pluijm, G., J. Kerr, C. Löwik, and P. Gehron Robey. 1993. $\beta 1$ and $\beta 3$ integrin subunits are involved in adhesion of breast cancer cells to extracellular bone matrix. J. Bone Miner. Res. 8:S136 (Abstr.).

46. van der Pluijm, G., H. Vloedgraven, S. Papapoulos, P. Gehron Robey, and C. Löwik. 1994. Integrins mediate adhesion of breast cancer cells to various stages of developing bone. J. Bone Miner. Res. 9:S421 (Abstr.).

47. Kitazawa, S., and S. Maeda. 1995. Development of skeletal metastases. Clin. Orthop. Relat. Res. 312:45-50.

48. von Kossa, J. 1901. Ueber die im Organismus künstlich erzeugbaren Verkalkungen. Beitr. Pathol. Anat. 29:163-202. 